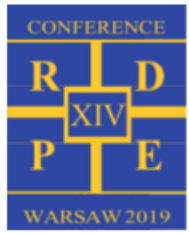

\title{
Oxy-combustion of agro and wood biomass in a fluidized bed
}

\author{
Katarzyna Kaczyńska ${ }^{1,}{ }^{*}$, Konrad Kaczyński ${ }^{1}$, and Piotr Pełka ${ }^{1}$ \\ ${ }^{1}$ Czestochowa U niversity of Technology, Faculty of M echanical Engineering and Computer Science, Institute of Thermal M achinery, \\ al. A rmii Krajowej 21, 42-201 Czestochowa, kgajewska@imc.pcz.pl, Poland
}

\begin{abstract}
Present trends in the global energy sector effectively drive the development of technologies using renewable energy sources and the improvement of combustion technology towards increasing its efficiency and removing environmentally harmful flue gases. One solution is to replace fossil energy sources with renewable sources, including biomass. The degree of biomass utilization depends on the size of resources and processing technology. There are more and more different types of biomass on the market. There are many technologies for its energetic use. In recent years, fluidized combustion technology has been considered as one of the main directions of development of professional energy in the world. M any units in the world in fluidized combustion technology use as primary or supplementary fuel: sludge, wood waste and biomass, as well as municipal waste, etc. Fluidized bed boilers also allow the implementation of the dynamically developing oxy-combustion technology, which perfectly fits the prevailing trends due to the key advantages of increased energy conversion, as well as the possibility of direct sequestration of carbon dioxide. During experimental research, the mass loss of biomass pellets of various origins was analyzed in an oxidizing and inert atmosphere in a two-phase flow with the use of inert material. The obtained results allow to state that the large variety of biomass offered by suppliers requires a thorough knowledge of its properties and determination of its impact on the process and installations when used in the power industry.
\end{abstract}

\section{Introduction}

Growing concerns on the greenhouse gas emissions and their potential impact on climate change demand not only the application of $\mathrm{CO}_{2}$ capture and storage (CCS) technologies to large point anthropogenic $\mathrm{CO}_{2}$ emission sources such as coal and natural gas fired power plants but also the implementation of $\mathrm{CO}_{2}$ negative combustion technologies such as B io-energy with Carbon Capture and Storage (BECCS) with in the next decades. [1,2]. B iomass is considered as a renewable fuel, a carbon-neutral energy source [3], and hence its combustion integrated with CCS can lead to negative $\mathrm{CO}_{2}$ emissions. B iomass has already captured worldwide attention in the context of greenhouse gas control even though fossil fuels are expected to retain their dominant role in the world energy supply in the coming decades [4]. Oxy-combustion is one of the most developed CCS technologies and considered as technically feasible and economically competitive for future commercial applications $[5,6,7]$. Oxy-combustion refers to fuel being burned in a mixture of oxygen and recycled flue gas (RFG). Unlike conventional air combustion plants that use air as the oxidant, an oxy-fired plant employs an A ir Separation U nit (ASU) to produce an almost pure oxygen stream. The oxygen stream is then combined with RFG to produce an oxygen enriched gas as the oxidant. The flue gas recycle is necessary to moderate the otherwise excessively high flame temperature that would result from fuel combustion in pure oxygen. After the removal of water and other impurities from the flue gas exhaust stream, high-purity CO2 (up to 95\%) is produced and almost ready for sequestration [1].
Among all the available combustion technologies, fluidized bed combustion (FBC) is often considered as the best choice for the combustion and/or co-combustion of biomass, waste and other low-quality solid fuels due to its fuel flexibility, long residence times, and uniform combustion temperatures. The characteristics of $F B C$ al so offers several advantages for its application in oxy-fuel systems [8]. Firstly, the difficulty of flue gas recirculation for temperature control in pulverized fuel (PF) applications could be reduced in circulating fluidized bed (CFB) by means of the bed material recirculation, since the specific heat of the solids is much higher than that of the recycled flue gas. Secondly, lower N Ox emissions and better sulphur removal are possible. Finally, it is easier to retrofit a fluidized bed boiler from air to oxy-fuel combustion as there will be no need for a new burner. The effects of oxy-fuel atmosphere and $\mathrm{O}_{2}$ concentration in fluidized bed systems firing different kinds of coal have been thoroughly investigated during the past years by a number of researchers [8-18] in which the advantages of oxy-combustion have been confirmed, namely: increased energy conversion and the possibility of carbon dioxide sequestration. In general, the experimental results showed that $\mathrm{NOx}$ emissions in oxy-fuel combustion with low 02 concentrations are lower than those obtained under airfiring atmosphere Furthermore, NOx emissions were found to increase with the increasing $\mathrm{O}_{2}$ concentrations in the oxy-fuel oxidant, which is as a result of a) the increase of the temperature in the furnace which elevates the concentrations of $\mathrm{O}$ and $\mathrm{OH}$ radicals and enhances $\mathrm{NO}$ formation and $b$ ) the lower gas velocity in the riser and longer residence time of fuel particles in the combustor, which may promote the fuel-N conversion into NOx 
precursors [13-16]. In some studies, an opposite trend was found, i.e. a decrease of $\mathrm{NOx}$ with the increasing $\mathrm{O}_{2}$ concentration in the oxy-fuel oxidant, as in the work of de las Obras-Loscertales et al. [17], The authors explained this trend by means of the different operational procedure used, comparing with other investigations: in their work [15], an increase in the oxygen concentration was compensated with an increase of the coal flow rate fed to the reactor, keeping constant the total gas flow rate and excess oxygen coefficient in all tests. As a result, more unconverted char was present in the bed, favouring the $\mathrm{NO}$ reduction on the char surface.

So far, few researchers have analyzed oxy-fuel combustion in fluidized bed reactors fueled with $100 \%$ biomass fuels, so further research is needed.

Biomass properties differ from those of coal in many important ways which results in different combustion behaviours [19]. For example, biomass generally has less carbon, more oxygen, higher hydrogen content and lower heating value. There are huge differences in volatile matter contents between biomass and coal: biomass can lose up to $90 \%$ of their masses (as volatiles) in its first stage of combustion [20].

Duan et al. [21] conducted a series of experiments firing three kinds of $\mathrm{C}$ hinese biomass fuels, i.e. rice husk, wood chips and dry wood flour, under air and oxy-fuel atmosphere in a $10 \mathrm{~kW}$ th CFB combustor. The main objective of their study was to investigate the pollutant emissions of the co-firing of biomass with coal under oxyfuel combustion conditions although experiments firing only the biomass fuels were also carried out for comparison purposes. They observed lower $\mathrm{NO}$ emissions in the oxy-fuel atmosphere compared with those with air combustion. This behaviour was explained as the result of the reduced yield of $\mathrm{NO}$ x precursors like $\mathrm{NH}_{3}$ during the devolatilization process and the enhanced $\mathrm{NO}$ reductions via char/N O/CO reactions under the oxy-fuel combustion conditions. The objective of the work [1] was oxy-fuel combustion of biomass fuels firing three kind of biomass fuels, two non-woody (miscanthus and straw) and one woody (wood), in a $20 \mathrm{~kW}$ th bubbling fluidized bed (BFB) combustor, studying the effects of the combustion atmosphere (air and oxy-fuel) and the oxygen concentration in the oxy-fuel oxidant on the gas emissions and temperature profiles. In contrast, work [21], unlike the abovementioned, was devoted to the analysis of the combustion of a single biomass particle in a fluidized bed in different oxidizing atmospheres. In this research, spherical 8-mm particles of wooden biomass (willow, Salix viminalis) were used. B iomass was combusted in a fluidized bed at $850{ }^{\circ} \mathrm{C}$ and various atmospheres: air atmosphere: $21 \% \mathrm{O}_{2}+79 \% \mathrm{~N}_{2}$ and oxidizing atmospheres: $21 \% \mathrm{O}_{2}+79 \% \mathrm{CO}_{2}, 30 \% \mathrm{O}_{2}+70 \% \mathrm{CO}_{2}$ and $40 \% \mathrm{O}_{2}+60 \% \mathrm{CO}_{2}$. The results of the experiment indicate that the composition of the oxidizing atmosphere strongly affects the combustion process of biomass fuels. The replacement of $\mathrm{N}_{2}$ in the combustion environment by $\mathrm{CO}_{2}$ resulted in a slight ignition delay and lower maximum mass loss during the combustion of raw biomass. Increasing the amount of oxidant resulted in shorter burning time. Unlike studies [21], the experiment described in this work was conducted using applications on the market of processed biomass fuels specifically dedicated to combustion in the energy sector.

\section{Motivations}

The aim of the experimental research was:

1) analysis of the oxy-combustion process of selected biomass fuels dedicated for combustion in technology with CFB,

2) comparison of the agro and wood biomass combusting process,

3) comparison of the combustion mechanism of selected pellets without inert material and in the conditions of the circulating fluidized bed,

\section{Experiment}

During the experimental research, the impact of inert material and oxidizing atmosphere on the mass loss of pellets of two types of biomass was analyzed: wood biomass - oak sawdust pellets and pellets from a mixture of sawdust $30 \%$ beech / 70\% oak) and agro-pellets from sunflower husk and pellets from straw. The temperature of $850^{\circ}$ was corresponds to the combustion temperature of fuels in professional fluidized bed boilers. The research was performed in air atmosphere and gas compound: $21 \% \mathrm{O}_{2}$ and $79 \% \mathrm{CO}_{2}, 25 \% \mathrm{O}_{2}$ and $75 \% \mathrm{CO}_{2}$, and $30 \%$ $\mathrm{O}_{2}$ and $70 \% \mathrm{CO}_{2}$. The research was carried out in a stream of inert material $\mathrm{Gs}=0 \mathrm{~kg} / \mathrm{m}^{2} \mathrm{~s}, 2,5 \mathrm{~kg} / \mathrm{m}^{2} \mathrm{~s}$ and $5 \mathrm{~kg} / \mathrm{m}^{2} \mathrm{~s}$. The values of the stream of inert material are characteristic for the upper and middle area of the real zone of the fluidized bed boilers.

\subsection{Experimental stand}

The research was carried out on a specially constructed test stand. The experimental stand made it possible to model the conditions of the circulating fluidized bed. the experimental stand is presented in Fig. 1. [11].

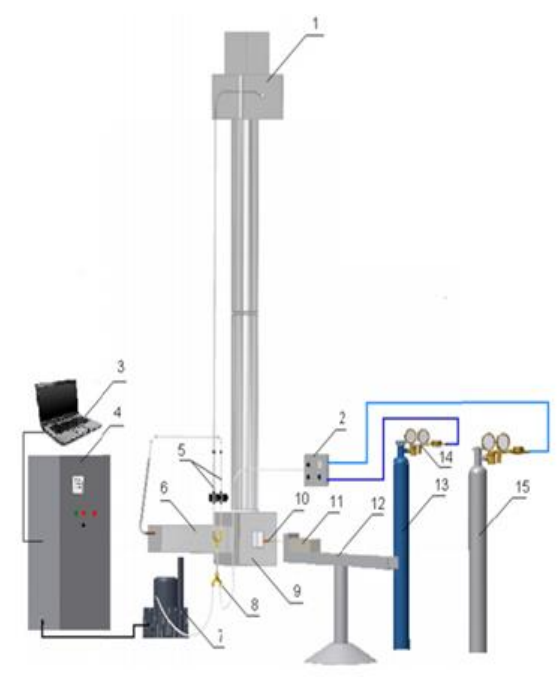

Fig. 1. The scheme of test apparatus. (1) vessel of inert material, (2) gas mixer, (3) PC-computer, (4) control panel, (5) rotametres, (6) gas heater, (7) ventilator, (8) T-connector, (9) combustion chamber, (10) coal particle, (11) tensometric branch scale, $(12)$ support, $(13,15)$ technical gases, $(14)$ reducer [1]. 


\subsection{Research material}

Four types of biomass pellets, each in the shape of a cylinder, were used for the study. Oak sawdust pellets, a mixture of beech and oak sawdust and straw had a diameter of $6 \mathrm{~mm}$, while the diameter of pellets from sunflower husk was $8 \mathrm{~mm}$. The mass of the samples was $0.73 \pm 0.03 \mathrm{~g}$. Table 1 contains the results of the technical analysis of the tested fuels.

Table 1. Results of technical analysis of biomass fuels.

\begin{tabular}{|c|c|c|c|c|c|}
\hline Pellets & Volatile [\%] & Moisture [\%] & Ash [\%] & Fixed coal [\%] & $\begin{array}{c}\text { Combustion } \\
\text { heat [MJ/kg] }\end{array}$ \\
\hline Oak sawdust & 79.6 & 8.7 & 1.2 & 10.5 & 18.2 \\
\hline 30\%beech and 70\%oak sawdust & 77.7 & 8.8 & 1.3 & 10.7 & 17.9 \\
\hline Sunflower husk & 73.8 & 8.4 & 5.5 & 12.3 & 19.8 \\
\hline Straw & 71.8 & 8.7 & 12.2 & 7.3 & 16.2 \\
\hline
\end{tabular}

\section{Results of the experiment}

Fig. 2. presents a comparison of pellets combustion time combusted at different conditions in a circulating fluidized bed. Fig. 3. presents percentage comparison of pellets combustion time during reduction of the combustion chamber temperature compared to the reference reference atmosphere (21\% oxygen). In all cases, according to the theory, a change in the combustion atmosphere consisting of an increase in the concentration of the oxidizer results in the reduction of the total loss of mass of the biomass pellets combusted. Supplying more oxidizer to the combustion area causes acceleration of the combustion process, therefore the loss of mass is accelerated due to the increased concentration of oxidizer and temperature, which is caused by the occurring chemical reactions. During combusting pellets without inert material, the wood biomass pellets were combusted the longest, and straw pellets the shortest. In the case of pellets combusting in the stream of inert material Gs $=2.5$ $\mathrm{kg} / \mathrm{m}^{2} \mathrm{~s}$, wood biomass pellets were the shortest combusted, the longest combusted pellets from sunflower husk. At this temperature the phenomenon of ash softening is manifested by the sticking of sunflower husk pellets through quartz sand. The sand forms a durable surface surrounding the incinerated pellet, consequently preventing the oxidizer from entering the combusted pellet. The residue after combusting sunflower husk pellet at $850^{\circ} \mathrm{C}$, tests were carried out in a stream of inert material at $\mathrm{Gs}=2.5 \mathrm{~kg} / \mathrm{m}^{2} \mathrm{~s}$ was shown in Fig. 4. A similar effect was observed when combusting straw pellets at $850^{\circ} \mathrm{C}$. The straw pellets combusted at $850{ }^{\circ} \mathrm{C}$ were sintered. The residue after combusting straw pellet at 850 ${ }^{\circ} \mathrm{C}$, tests were carried out in a stream of inert material at Gs $=2,5 \mathrm{~kg} / \mathrm{m}^{2} \mathrm{~s}$ was shown in Fig. 5. With an increased value of the inert material stream to Gs $=5 \mathrm{~kg} / \mathrm{m}^{2} \mathrm{~s}$, similar to $\mathrm{Gs}=2.5 \mathrm{~kg} / \mathrm{m}^{2} \mathrm{~s}$ of inert, the longest combusted pellets from sunflower husk, and the shortest pellets from forest biomass. In the case of agro biomass combustion, as in the case of combustion in Gs $=2.5$ $\mathrm{kg} / \mathrm{m}^{2} \mathrm{~s}$, during the combusting of pellets from sunflower husk, the formation of a coating was observed, which was partially broken down as a result of the mechanical impact of inert material - Fig. 6. On the other hand, the sinter was formed during combustion of straw was completely broken down.

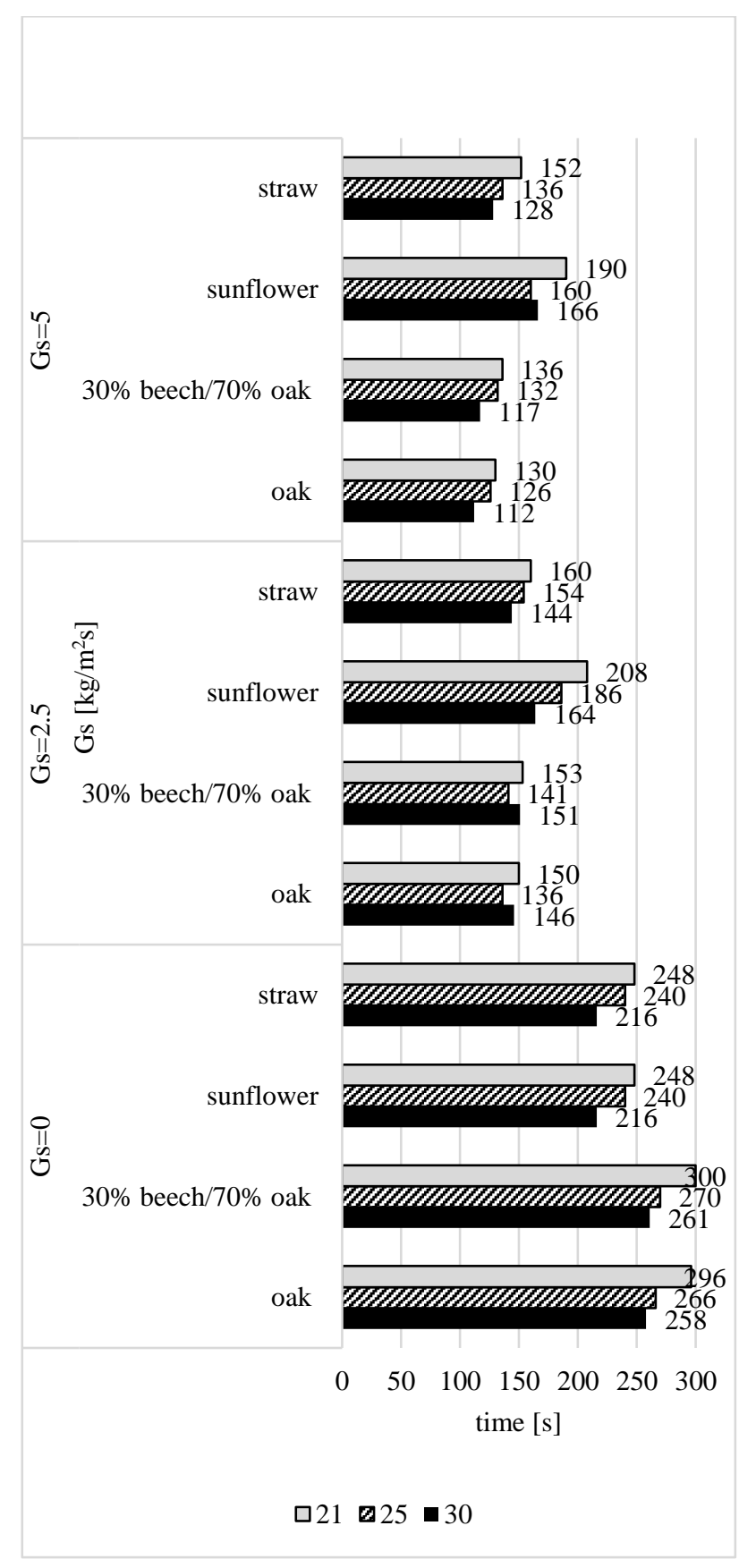

Fig. 2. Comparison of pellets combustion time combusted at different conditions in a circulating fluidized bed. 


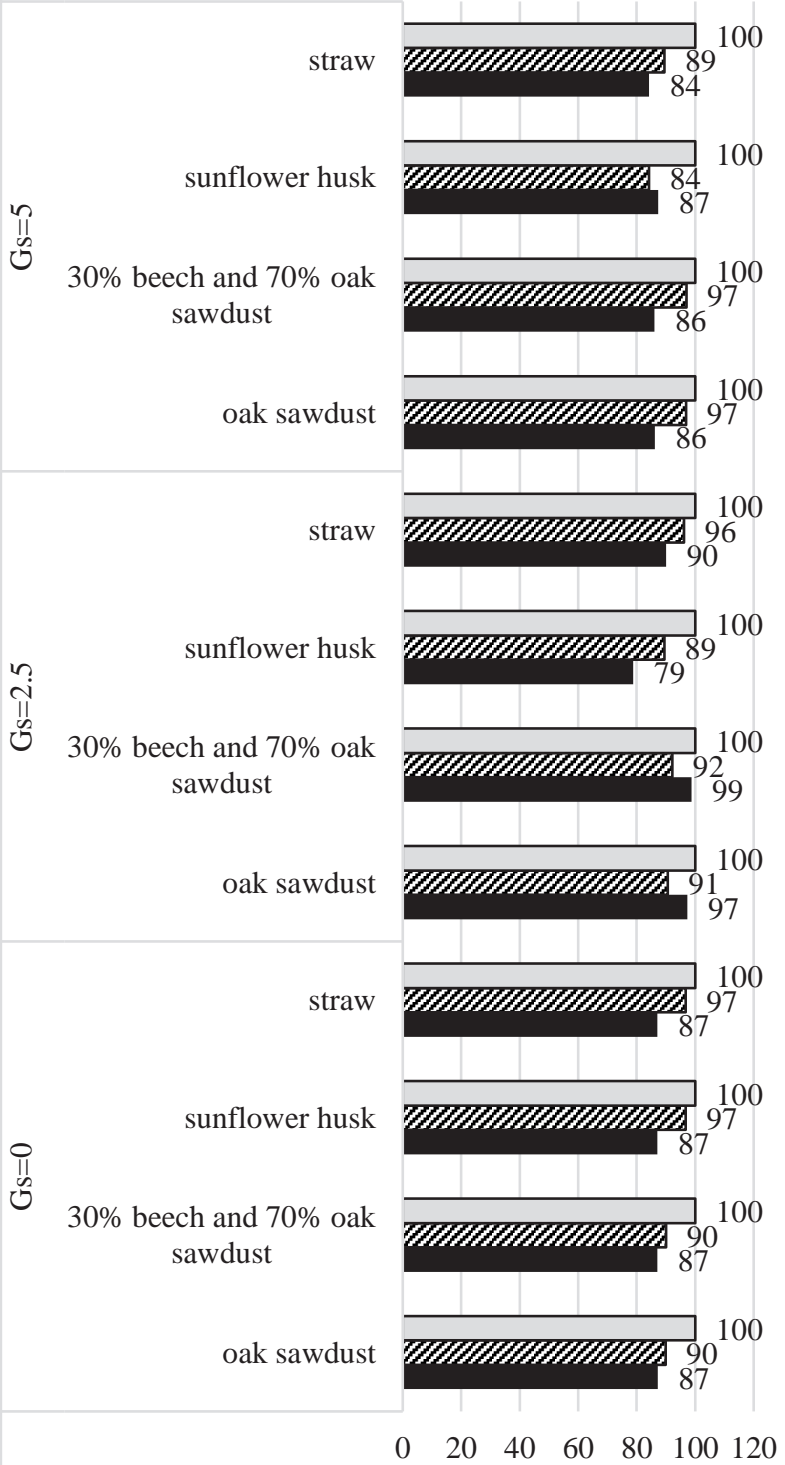

$\square 21 \square 25 \square 30$

Fig. 3. Combustion times during the change of the oxidizing atmosphere compared to the reference atmosphere $(21 \%$ oxygen) of all types of pellets.

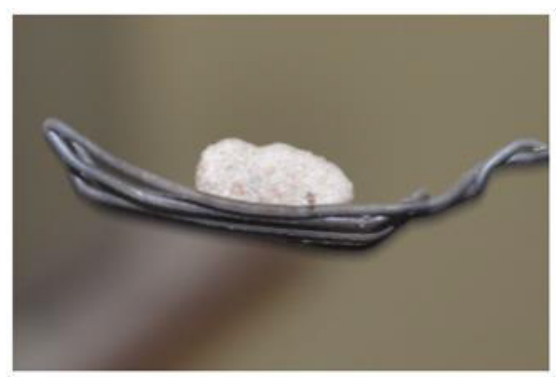

Fig. 4. The residue after combusting sunflower husk pellet at $850^{\circ} \mathrm{C}$, tests were carried out in a stream of inert material at Gs $=2,5 \mathrm{~kg} / \mathrm{m}^{2} \mathrm{~s}$.

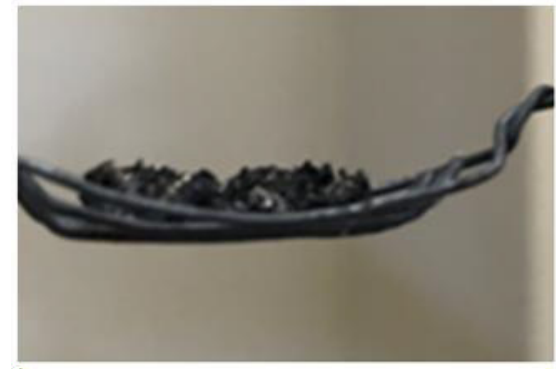

Fig 5. The residue after combusting straw pellet at $850^{\circ}$ $C$, tests were carried out in a stream of inert material at $\mathrm{Gs}=2,5 \mathrm{~kg} / \mathrm{m}^{2} \mathrm{~s}$.

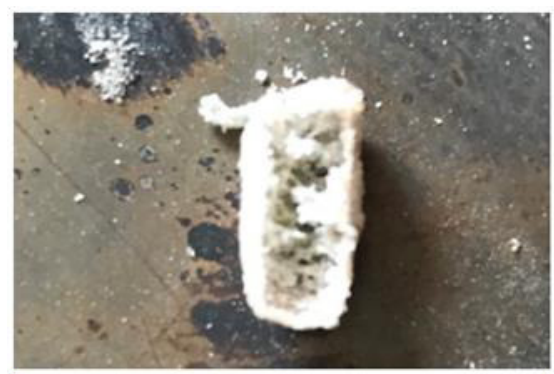

Fig 6. Residue after combusting sunflower husk pellets at $850^{\circ} \mathrm{C}$ and $\mathrm{Gs}=5 \mathrm{~kg} / \mathrm{m}^{2} \mathrm{~s}$.

Fig. 7. shows a comparison of pellet combustion times depending on the stream of inert material combusted at different at different atmosphere (Gs $=0$ reference level). The presence of inert material to varying degrees accelerates the mass loss of all types of pellets in all atmospheres. In the case of wood biomass, the combustion in the stream of material Gs $=2.5 \mathrm{~kg} / \mathrm{m}^{2} \mathrm{~s}$ in each atmosphere is shorter by about $50 \%$ compared to incineration without inert material. However, further increase of the inert material stream to Gs $=5 \mathrm{~kg} / \mathrm{m}^{2} \mathrm{~s}$ accelerated the combustion process by a further $10 \%$. In the case of combusting sunflower husk pellets compared to incineration without inert material, the combustion time in the stream Gs $=2.5 \mathrm{~kg} / \mathrm{m}^{2} \mathrm{~s}$ is reduced by about $20-30 \%$. Increasing the value of inert material stream to Gs $=5$ $\mathrm{kg} / \mathrm{m}^{2} \mathrm{~s}$ resulted in shortening the combustion time in the case of two oxidizing atmospheres of $21 \%$ and $25 \%$ oxygen by about $10 \%$, while in the case of $30 \%$ oxygen concentration, the combustion time was extended by $1 \%$. In the case of straw pellets compared to incineration without inert material, the combustion time in the stream of inert material Gs $=2.5 \mathrm{~kg} / \mathrm{m}^{2} \mathrm{~s}$ is reduced by about $35 \%$. Increasing the value of the stream of inert material caused a reduction of the combustion time by about $10 \%$. 


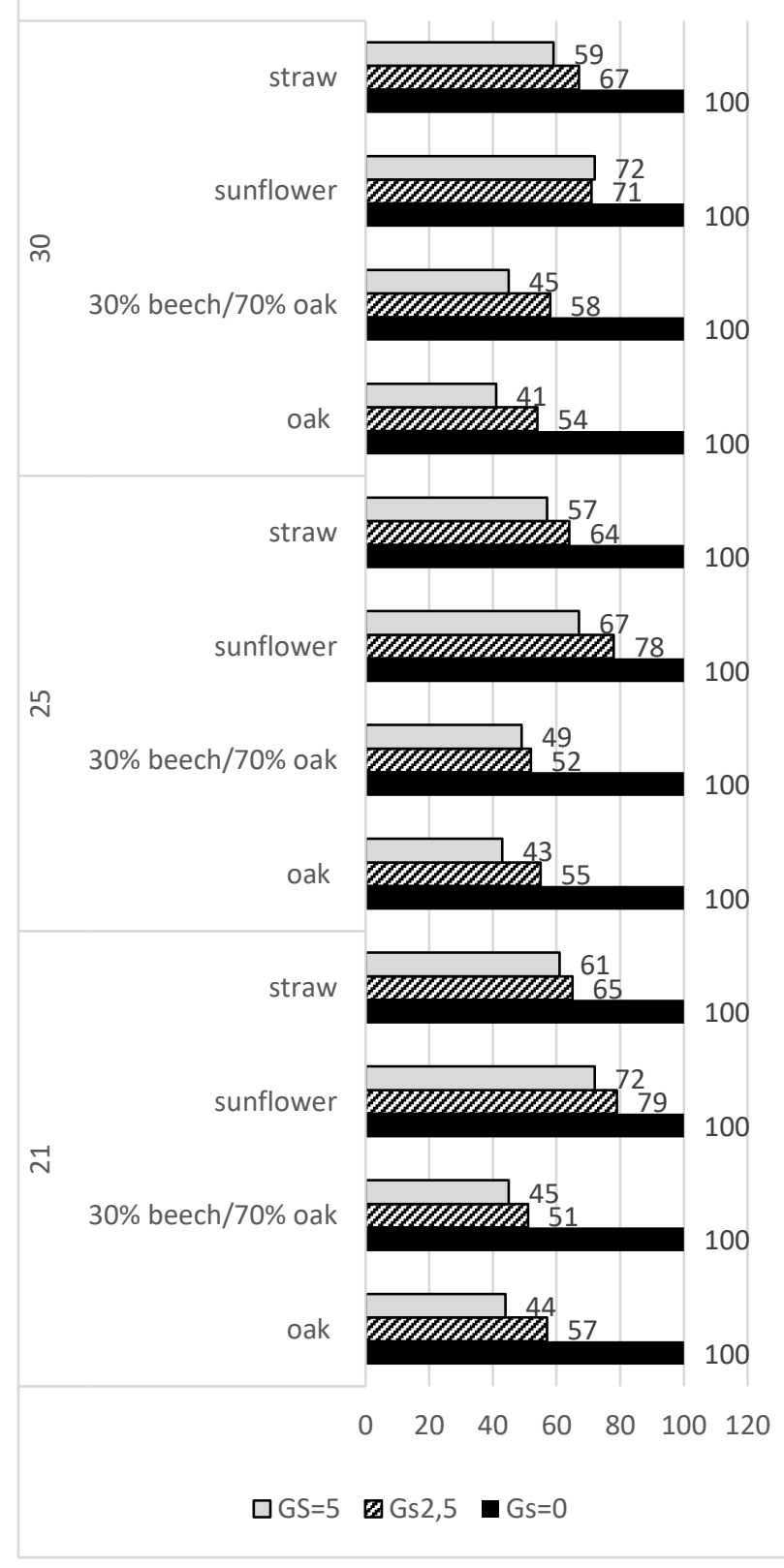

Fig. 7. Comparison of pellet combustion times depending on the value of the Gs material stream combusted at different atmosphere (Gs $=0$ reference level).

\section{Conclusions}

B iomass is a source of energy characterized by dispersion and different fuel properties compared to fossil fuels, among which there should be mention of lower calorific value and high moisture content. Nevertheless, biomass has the highest energy potential as it accumulates a large amount of energy that can be obtained from renewable sources. One of the best methods for direct biomass combustion is that of fluidized bed technology, characterized by high efficiency and stable working conditions as well as the possibility of easily adapting the installation for oxygen combustion of fuels.

The analysis carried out as part of the work facilitates the formulation of the following conclusions:

a) Increasing the concentration of oxidant in the atmosphere of combustion causes the reduction of the time of total mass loss of combusted particles of all tested biomass fuels. A ccording to the theory of providing more oxidizer to the combustion area, it accelerates the combustion process, therefore the mass loss is accelerated.

b) The introduction of inert material into the combustion zone of the particle resulted in the reduction of the total combustion time for all tested fuels in comparison with the combustion time without its participation in each analysed oxidizing atmosphere.

c) In case of combustion of oak sawdust pellets, the inert material at $\mathrm{Gs}=2.5 \mathrm{~kg} / \mathrm{m}^{2} \mathrm{~s}$, the total combustion time lasts about $45 \%$ shorter than without the inert material in each analysed oxidizing atmosphere. A further increase in the value of the inert material stream results in the reduction of the combustion time by approximately $10 \%$.

d) In the case of the combustion of the sunflower husk pellets in an inert material stream, the ash softening temperature was exceeded and the sample sand was glued through the quartz sand in each analysed oxidizing atmosphere. In the case of combusting sunflower husk pellets in all atmospheres compared to incineration without inert material, the combustion time in the stream $\mathrm{Gs}=2.5 \mathrm{~kg} / \mathrm{m}^{2} \mathrm{~s}$ is reduced by about $20-30 \%$. Increasing the value of inert material stream to $\mathrm{Gs}=5 \mathrm{~kg} / \mathrm{m}^{2} \mathrm{~s}$ resulted in shortening the combustion time by another $10 \%$.

e) During the combustion of straw pellets in the flow of inert material, in each analysed oxidizing atmosphere the formation of sinters was observed, which at the lower value of the stream of inert material at the level of $G s=$ $2.5 \mathrm{~kg} / \mathrm{m}^{2} \mathrm{~s}$ did not break down. During the intensification of the flow of inert material, the sinters were fragmented due to the interaction of inert material. In the case of straw pellets compared to incineration without an inert material, the combustion time in the stream of inert material $\mathrm{Gs}=$ $2.5 \mathrm{~kg} / \mathrm{m}^{2} \mathrm{~s}$ is reduced by about $35 \%$. Increasing the value of the stream of inert material caused a reduction of the combustion time by about $10 \%$.

Based on the conducted experimental research, it was found that forest and agricultural biomass can be successfully used during oxy-combustion in boilers with a circulating fluidized bed under several conditions. Due to the chemical composition agricultural biomass (high content of chlorine and elements alkaline) and low temperatures softening and melting ash, it should be combusted under appropriate controlled conditions. Due to significant differences in biomass quality first of all, quality should be monitored fuel supplied to the combustion chamber.

\section{References}

1. Sher F., Pans M.A., Sun Ch., Snape C., Liu H., Oxyfuel combustion study of biomass fuels in a $20 \mathrm{kWth}$ 
fluidized bed Combustor, Fuel, 215, 778-786, (2018).

2. Greinert A., Mrówczyńska M., Szefner W., The Use of Waste Biomass from the Wood Industry and Municipal Sources for Energy Production, Sustainability, 11, 3083, (2019).

3. Pradhana P., Mahajanib S. M., Aroraa A., Production and utilization of fuel pellets from biomass: A review, Fuel Processing Technology, 181, 215-232, (2018).

4. The International Energy Agency, Global Energy \& $\mathrm{CO}_{2}$ Status Report 2018, The latest trends in energy and emissions in 2018, (2018).

5. Toftegaard M.B., Brix J., Jensen P.A., Glarborg P., Jensen A.D., Oxy-fuel combustion of solid fuels. Prog Energy Combust Sci, 36(5):581-625 (2010).

6. Scheffknecht G., Al-Makhadmeh L., Schnell U., Maier J., Oxy-fuel coal combustion - anreview of the current state-of-the-art. Int $J$ Greenhouse Gas Control, 5:S16-35, (2011).

7. Wall T., Liu Y., Spero C., Elliott L., Khare S., Rathnam R., et al. An overview on oxyfuel coal combustion-State of the art research and technology development. Chem Eng Res Des; 87(8):1003-16 (2009).

8. Mathekga H.I., Oboirien B.O., N orth B.C., A review of oxy-fuel combustion in fluidized bed reactors. Int J Energy Res, 40(7):878-902 (2016).

9. Bis Z., Czakiert T., Nowak W., Spalanie w atmosferach modyfikowanych tlenem kierunkiem rozwoju dla kotłów CWF; Energetyka i Ekologia; str. 713-718 (2008).

10. Bisio G., Bosio A., Rubatto G., Thermodynamics applied to oxygen enrichment of combustion air, Energy Conversion and Management, Vol. 43, pp. 2589-2600 (2002).

11. Pełka P., Analysis of a coal particle mass loss burning in flow of inert material. Combust. Flame, 156, 1604, (2009).

12. Kaczyński K., Kaczyńska K., Pełka P., Analiza ubytku masy ziarna węgla w atmosferze utleniającej oraz obojętnej w zmiennej temperaturze panującej w komorze paleniskowej w dwufazowym przepływie z udziałem materiału inertnego, Rynek Energii, $\mathrm{Nr}$ 1(140), 87-97, (2019).

13. Duan L., Zhao .C., Zhou W., Qu C., Chen X.. Effects of operation parameters on NO emission in an oxyfired CFB combustor. Fuel Process Technol, 92(3):379-84, (2011).

14. Singh R.I., Kumar R., Current status and experimental investigation of oxy-fired fluidized bed. Renewable Sustainable Energy Rev, 61:398-420 (2016).

15. Roy B., Chen L.G., Bhattacharya S., Nitrogen oxides, sulfur trioxide, and mercuryemissions during oxyfuel fluidized bed combustion of victorian brown coal, Environ Sci Technol, 48(24):14844-50, (2014).

16. Hofbauer G., Beisheim T., Dieter H., Scheffknecht G., Experiences from oxy-fuel combustion of bituminous coal in a $150 \mathrm{kWth}$ circulating fluidized bed pilot facility. In: Rokke NA, Svendsen H, editors. 7th Trondheim Conference on $\mathrm{CO}_{2}$ capture, transport and storage. Amsterdam: Elsevier Science Bv, p. 24 $30,(2014)$

17. de las Obras-Loscertales M., Mendiara T., Rufas A., de Diego L.F., García-Labiano F., Gayán P., et al. NO and $\mathrm{N}_{2} \mathrm{O}$ emissions in oxy-fuel combustion of coal in a bubbling fluidized bed combustor, Fuel, 150:14653 (2015).

18. Jia L., Tan Y., Anthony E.J., Emissions of $\mathrm{SO}_{2}$ and NOx during oxy-fuel CFB combustion tests in a mini-circulating fluidized bed combustion reactor, Energy Fuels, 24:910-5 (2010)

19. Khana A.A., de Jong W., Jansens P.J., Spliethoff H., Biomass combustion in fluidized bed boilers: Potential problems and remedies, Fuel Processing Technology, Volume 90, Issue 1, 21-50, (2009).

20. Niu Y.Q., Tan H.Z., Hui S.E., Ash-related issues during biomass combustion: alkaliinduced slagging, silicate melt-induced slagging (ash fusion), agglomeration, corrosion, ash utilization, and related countermeasures. Prog Energy Combust, Sci,52:161, (2016)

21. Kosowska-Golachowska M., Kijo-Kleczkowska A., Luckos A., Wolski K., Musiał T.: Oxy-combustion of biomass in a circulating fluidized bed. Archives of Thermodynamics, vol. 37, no. 1, p.17-30, (2016). 